\title{
IMPACT OF SOW MILK PROTEIN POLYMORPHISM ON PIGLET REARING
}

\author{
Ewa Skrzypczak ${ }^{1}$, Marek Babicz ${ }^{2}$, Karolina Szulc ${ }^{1}$, \\ Anna Walendowska ${ }^{3}$, Anna Panek ${ }^{1}$ \\ 'Department of Pig Breeding and Production, Poznań University of Life Sciences, \\ Wołyńska 33, 60-637 Poznań, Poland \\ ${ }^{2}$ Department of Pig Breeding and Production Technology, University of Life Sciences in Lublin, \\ Akademicka 13, 20-950 Lublin, Poland \\ ${ }^{3}$ Department of Cattle Breeding and Milk Production, Poznań University of Life Sciences, \\ Wojska Polskiego 71 A, 60-625 Poznań, Poland \\ Corresponding author: karolasz@jay.au.poznan.pl
}

\begin{abstract}
The aim of the investigations was to ascertain interrelationships between polymorphic fractions of milk proteins and rearing results of piglets from Zlotnicka White sows. The experimental material comprised 20 sows of the native Zlotnicka White breed. Pigs of this breed are included in the National Genetic Resources Conservation Programme. Investigations included two successive (2nd and 3rd) lactations of sows during which the following parameters were determined: number and weight of piglets on days $1,7,14,21$ and 28 ; weight gains of individual piglets during the period from day 1 to 7, from day 8 to 14 , from day 15 to 21 and from day 22 to 28 ; as well as mortality for the entire period of rearing, i.e. from day 1 to day 28 of age. A total of $\mathbf{4 2 5}$ piglets born in 40 litters (20 sows $\times 2$ lactations) were investigated. As a result of electrophoretic separations, the following four protein fractions were isolated from sow milk: as1-casein (CSN1S1), genotypes AA, AB, BB and $B C$; $\beta$-casein (CSN2), genotypes $A A, A B$ and $B B$; $\kappa$-casein (CSN3), genotypes $A A, A B$ and BB; $\beta$-lactoglobulin (LGB), genotypes AA and BB. The present study showed that milk from sows of AA CSN1S1 and AA LGB genotypes appeared to be more valuable and nourishing, as indicated by the fact that these sows reared piglets which were characterized by the best production results, i.e. body weight, weight gains and the lowest percentage mortality. The least dynamic results were obtained by piglets originating from litters of sows of the AA-CSN3 genotype.
\end{abstract}

Key words: sow milk, milk protein polymorphism, piglet rearing, Zlotnicka White

The basic food of piglets during their first days of life is mother's colostrum and milk. Their composition and nutritional value exert a remarkable impact on piglet rearing results (Rekiel et al., 2011; Skrzypczak et al., 2012). 
In Poland, rearing results are far from satisfactory. Until the age of 21 days, losses of piglets are estimated at 20-30\% and, in the later period, they reach $20 \%$ (Boruta et al., 2009). There may be numerous factors causing such great losses: sow's condition, litter weight, litter size, frequency of suckling, lactation curve, and number of production cycles. Therefore, every effort should be made to ensure the best possible quality and quantity of colostrum and milk (Buczyński et al., 2006).

Due to their high nutritive value, milk proteins play a very significant role in the rearing of animals; they provide an important source of calcium (Gigli et al., 2007), regulate the immune system (Flower et al., 2000), exhibit antibacterial activities (Chaneton et al., 2011) and take part in fatty acid metabolism (Perez and Calvo, 1995). There is a growing interest in proteins, in particular whey proteins, as products which exhibit health-promoting properties (Ha and Zemel, 2003; Król et al., 2008, 2010).

Investigations have already been conducted for many years with the aim of determining genetic markers of animal production traits. In cattle breeding, attention was focused on milk protein genes (Zwierzchowski, 2009), in particular on the study of dairy cattle breeds and the interrelationships between polymorphic forms and yields, chemical composition and physicochemical qualities of milk (Litwińczuk et al., 2006; Michalcova and Krupova, 2007; Meza-Nieto et al., 2010). Investigations on milk protein polymorphism made it possible to determine differences and similarities between herds within breeds and to register genetic changes resulting from breeding and natural selection. In parallel, investigations are also carried out concerning milk protein polymorphism in meat breeds. At the present time, research results regarding milk protein polymorphism are so reliable that a genetic variant of milk protein is introduced increasingly frequently in breeding work as an additional selection parameter (Litwińczuk et al., 2006; Zwierzchowski, 2009). This is a very important issue from the economic point of view.

Little research has been performed on other animal species, especially concerning the impact of milk protein polymorphism on progeny production results. Investigations on the occurrence of milk protein polymorphism in sows and identification of its genetic sequence could become an important parameter in swine selection and piglet rearing.

That is why the objective of this research project was to gather information connected with relationships between polymorphic fractions of milk protein and results of piglet rearing.

\section{Material and methods}

\section{Animal material}

Twenty sows of the native Złotnicka White breed were used in the present experiment. Investigations were conducted in the period from November 2009 to December 2010 on a farm $\left(54^{\circ} 48^{\prime} \mathrm{N}, 16^{\circ} 83^{\prime} \mathrm{E}\right)$ rearing pigs of native domestic breeds, situated near Poznań in the Wielkopolskie Voivodeship, Poland. 
The origin of the experimental animals was known because the Department of Pig Breeding and Production at the Poznań University of Life Sciences had a complete pedigree and breeding documentation of the breed. Złotnicka pigs are covered by the National Genetic Resources Conservation Programme (Szulc et al., 2012). The research comprised two consecutive (2nd and 3rd) lactations of sows. All experimental sows were housed in identical conditions that met all welfare requirements. The sows were housed in single farrowing crates from about day 10 before parturition to the 4th week of lactation. They were fed individually with standard total mixed rations according to Polish Nutrient Requirements of Pigs (1993). Feed was supplied twice a day at $2 \mathrm{~kg}$ per ration with ad libitum access to water. Table 1 presents the composition of diets fed to sows.

Table 1. Composition and values of the feed mixture

\begin{tabular}{|c|c|c|}
\hline No. & Nutrients & Value \\
\hline 1. & Metabolizable energy & $12.94 \mathrm{MJ}$ min. \\
\hline 2. & Crude protein & $16 \% \min$. \\
\hline 3. & Crude fibre & $7.5 \% \max$ \\
\hline 4. & Crude ash & $4.8-6.8 \% \min .-\max$ \\
\hline 5. & Crude fat & $4.2-6.2 \% \min .-\max$ \\
\hline 6. & $\mathrm{Ca}$ & $1.0 \% \mathrm{~min}$. \\
\hline 7. & P-digestible & $0.32 \% \min$. \\
\hline 8. & $\mathrm{Na}$ & $0.20 \% \mathrm{~min}$. \\
\hline 9. & Lysine & $0.93 \% \min$. \\
\hline 10. & Methionine & $0.26 \% \min$. \\
\hline 11. & Met.+Cyst. & $0.54 \% \mathrm{~min}$. \\
\hline 12. & Tryptophan & $0.16 \% \min$. \\
\hline 13. & Threonine & $0,64 \% \mathrm{~min}$. \\
\hline
\end{tabular}

In addition, diets were rich in active substances, i.e. vitamins $\mathrm{E}, \mathrm{A}$ and $\mathrm{D}_{3}$, organic acids, 3-phytase as well as $\mathrm{Cu}$.

Sows from the discussed experiments were mated naturally and progeny from 20 litters were derived from a single sire. Parturitions on the farm were all supervised by a zootechnician.

\section{Obtaining material for investigations and analytical methods}

Sows were milked by hand (on the second day of lactation) from each active nipple in the amount of about $7 \mathrm{ml}$ (from the whole gland) into marked test tubes following earlier intramuscular injection of approximately $3 \mathrm{ml}$ of oxytocin. After collection, the milk was cooled down to $20^{\circ} \mathrm{C}$ and then polymorphic fractions of milk proteins were determined. Protein separation was conducted with the assistance of horizontal starch gel electrophoresis. Hydrolyzed potato starch was used to prepare $25 \%$ gel by bringing the mixture of $30 \mathrm{~g}$ starch, $100 \mathrm{ml}$ distilled water and $16.8 \mathrm{ml}$ Tris-citric buffer to the temperature of $90^{\circ} \mathrm{C}$. The buffer solution was prepared by using $92.8 \mathrm{~g}$ TRIS and $13.8 \mathrm{~g}$ citric acid which were dissolved in 11 of distilled water (solution $\mathrm{pH}$ 8.6). Once the gel clarified, $72 \mathrm{~g}$ of urea was added and it was heated again to $90^{\circ} \mathrm{C}$. After consecutive clarification, the gel was deaerated 
and cooled down to $50^{\circ} \mathrm{C}$ after which $1 \mathrm{ml}$ of 2-mercaptoethanol was added and after thorough mixing, it was spread uniformly on a plate and placed under cover for the period of 24 hours in a refrigerator at $3^{\circ} \mathrm{C}$. After this period, gel was prepared to allow blotting paper soaked in milk to be placed on it. This was achieved by making slits in the gel. Milk samples were subjected to centrifugation at $3000 \mathrm{rpm}$ for 10 minutes accompanied by cooling and then flaked fat was removed. Next, from each sample, $2 \mathrm{ml}$ of defatted milk was collected to which one drop of 2-mercaptoethanol was added and, after mixing, left for the period of 15 minutes. Blotting paper soaked in milk was placed on slits made in gel (10 blotting papers per plate). Veronal buffer was used in tanks with electrodes. The buffer was prepared using $10.3 \mathrm{~g}$ veronal natrium and $1.87 \mathrm{~g}$ diethylbarbituric acid which were dissolved in 11 of distilled water. The plate with the blotting paper on gel was placed in tanks with electrodes to which Electrophoresis Power Supply apparatus (EPS 3500, Pharmacia Biotech) was connected, using $230 \mathrm{~V}$ voltage (initial current intensity of about $40 \mathrm{~mA}$ which reached about $25 \mathrm{~mA}$ at the end of the process). The electrodes were connected in such a way as to cause the migration to run from cathode to anode. The current was allowed to flow for the period of 23 hours.

After electrophoresis, the gel was removed from the plate and placed in a container with staining fluid for about 8 minutes. The staining fluid was prepared by dissolving $0.75 \mathrm{~g}$ amido black in $1000 \mathrm{ml}$ of $1 \%$ acetic acid. The stained gel was placed in decolourizing fluid (1\% acetic acid) and left for 24 hours. After decolourization, a spectrum of protein electrophoretic separation appeared on the gel on which its polymorphism could be identified. The application of this type of electrophoresis allowed simultaneous isolation of 4 protein fractions, i.e. $\alpha$ s1-casein (CSN1S1), $\beta$ casein (CSN2), $\kappa$-casein (CSN3) and $\beta$-lactoglobulin (LGB) (Table 2).

Table 2. Protein fractions isolated

\begin{tabular}{l|c}
\hline \multicolumn{1}{c|}{ Fraction } & Genotype \\
\hline as1-casein & AA \\
(CSN1S1) & AB \\
& BB \\
& BC \\
$\beta$-casein & AA \\
(CSN2) & AB \\
& BB \\
$\kappa$-casein & AA \\
(CSN3) & AB \\
& BB \\
$\beta$-lactoglobulin & AA \\
(LGB) & BB \\
\hline
\end{tabular}

Twenty-four hours after parturition, piglets were individually tagged and their sex identified. The following parameters were determined in the course of the trial: 
number and weight of piglets on days 1, 7, 14, 21 and 28 of age; weight gains of individual piglets during the periods from day 1 to 7 , from day 8 to 14 , from day 15 to 21 and from day 22 to 28 ; and mortality for the entire period of rearing, i.e. from day 1 to 28 .

A total of 425 piglets born in 40 litters (20 sows $\times 2$ lactations) were investigated.

\section{Statistical analysis}

The data obtained was statistically analysed using SAS package ver. 8.11 (2007) with the assistance of the normality test (UNIVARIATE), using multivariate analysis of variance with PROC GLM LSM (body weights, weight gains and deaths of piglets as well as milk production of sows between individual protein genotypes were compared). The results of these calculations were presented as least square means (LSM) and standard errors (SE).

For discrete random variables (the number of piglets aged 1, 7, 14, 21 and 28 days), probit transformation described by Lynch and Welsh (1998) was applied, which makes transformations from discrete random variables to continuous random variables possible.

The number of casein and lactoglobulin phenotypes as well as the frequency of alleles and genotypes for individual proteins was calculated according to the Hardy-Weinberg principle of distribution of genotypes and phenotypes. The $\chi^{2}$ test was used in the calculations.

Milk yields of sows were indirectly calculated using the following formula according to Williams (1995):

\section{(piglet weight on day 28 - piglet weight on day 1) $\times 3.8 \mathrm{~kg}$}

In the statistical models applied for the analysis, apart from the main effects under investigation, other effects were also taken into consideration:

Season (autumn, winter, spring, summer).

Lactation of sows (number of lactations initiated by the sows under investigation).

Piglets' sex (male, female).

\section{Results}

Table 3 shows protein fractions separated during the electrophoresis. $\alpha$ s 1-casein (CSN1S1) turned out to be the most diversified fraction. Four genotypes: AA, AB, $\mathrm{BB}$ and $\mathrm{BC}$ were identified in this fraction compared to only 2 homozygous genotypes (AA and $\mathrm{BB}$ ) identified in $\beta$-lactoglobulin (LGB). The other proteins were characterized by 3 genotypes: $\mathrm{AA}, \mathrm{AB}$ and $\mathrm{BB}$. Allele $\mathrm{B}$ was found to occur more frequently than allele $\mathrm{A}$ in the three protein fractions. 
Table 3. The frequency of alleles and genotypes controlling milk protein polymorphism

\begin{tabular}{l|c|c|c|c}
\hline Fraction & Genotype & $\begin{array}{c}\text { Number } \\
\text { of genotypes }\end{array}$ & $\begin{array}{c}\text { Genotype } \\
\text { frequency }\end{array}$ & $\begin{array}{c}\text { Allele } \\
\text { frequency }\end{array}$ \\
\hline CSN1S1 & AA & 2 & 0.10 & $\mathrm{~A}=0.20$ \\
& $\mathrm{AB}$ & 4 & 0.20 & $\mathrm{~B}=0.75$ \\
& $\mathrm{BB}$ & 12 & 0.60 & $\mathrm{C}=0.05$ \\
CSN2 & $\mathrm{BC}$ & 2 & 0.10 & \\
& $\mathrm{AA}$ & 14 & 0.70 & $\mathrm{~A}=0.75$ \\
& $\mathrm{AB}$ & 2 & 0.10 & $\mathrm{~B}=0.25$ \\
CSN3 & $\mathrm{BB}$ & 4 & 0.20 & \\
& $\mathrm{AA}$ & 4 & 0.20 & $\mathrm{~A}=0.45$ \\
& $\mathrm{AB}$ & 10 & 0.50 & $\mathrm{~B}=0.55$ \\
LGB & $\mathrm{BB}$ & 6 & 0.30 & \\
& $\mathrm{AA}$ & 4 & 0.20 & $\mathrm{~A}=0.20$ \\
& $\mathrm{BB}$ & 16 & 0.80 & $\mathrm{~B}=0.80$ \\
\hline
\end{tabular}

Table 4. Effect of $\alpha$ S1-casein (CSN1S1) genotype on piglet rearing

\begin{tabular}{|c|c|c|c|c|c|}
\hline \multirow[b]{2}{*}{ Traits } & & \multicolumn{4}{|c|}{ CSN1S1 genotype } \\
\hline & & $\begin{array}{c}\text { AA } \\
\mathrm{n}=30\end{array}$ & $\begin{array}{c}\mathrm{AB} \\
\mathrm{n}=88\end{array}$ & $\begin{array}{c}\mathrm{BB} \\
\mathrm{n}=264\end{array}$ & $\begin{array}{c}\mathrm{BC} \\
\mathrm{n}=43\end{array}$ \\
\hline \multirow{2}{*}{$\begin{array}{l}\text { Weight of piglets } \\
\text { aged } 7 \text { days }(\mathrm{kg})\end{array}$} & LSM & $2.83 \mathrm{~A}$ & $2.32 \mathrm{~B}$ & $2.42 \mathrm{~B}$ & $2.40 \mathrm{~B}$ \\
\hline & $\mathrm{SE}$ & 0.09 & 0.06 & 0.03 & 0.08 \\
\hline \multirow{2}{*}{$\begin{array}{l}\text { Weight of piglets } \\
\text { aged } 14 \text { days }(\mathrm{kg})\end{array}$} & LSM & $5.24 \mathrm{~A}$ & $4.33 \mathrm{~B}$ & $4.30 \mathrm{~B}$ & $4.32 \mathrm{~B}$ \\
\hline & $\mathrm{SE}$ & 0.17 & 0.11 & 0.06 & 0.15 \\
\hline \multirow{2}{*}{$\begin{array}{l}\text { Weight of piglets } \\
\text { aged } 21 \text { days }(\mathrm{kg})\end{array}$} & LSM & $7.04 \mathrm{Aa}$ & $5.22 \mathrm{~B}$ & $6.17 \mathrm{Ab}$ & $5.36 \mathrm{~B}$ \\
\hline & $\mathrm{SE}$ & 0.39 & 0.18 & 0.11 & 0.27 \\
\hline \multirow{2}{*}{$\begin{array}{l}\text { Weight of piglets } \\
\text { aged } 28 \text { days }(\mathrm{kg})\end{array}$} & LSM & $7.43 \mathrm{a}$ & 7.14 & 6.65 & $6.56 \mathrm{~b}$ \\
\hline & SE & 0.36 & 0.26 & 0.15 & 0.34 \\
\hline \multirow{2}{*}{$\begin{array}{l}\text { Growth of piglets } \\
\text { from } 1 \text { to } 7 \text { days of age }(\mathrm{kg})\end{array}$} & LSM & $1.27 \mathrm{~A}$ & $0.89 \mathrm{~B}$ & $0.97 \mathrm{~B}$ & $0.90 \mathrm{~B}$ \\
\hline & $\mathrm{SE}$ & 0.07 & 0.04 & 0.03 & 0.06 \\
\hline \multirow{2}{*}{$\begin{array}{l}\text { Growth of piglets } \\
\text { from } 8 \text { to } 14 \text { days of age }(\mathrm{kg})\end{array}$} & LSM & $2.40 \mathrm{~A}$ & $1.98 \mathrm{~B}$ & $1.86 \mathrm{~B}$ & $1.90 \mathrm{~B}$ \\
\hline & $\mathrm{SE}$ & 0.13 & 0.08 & 0.05 & 0.11 \\
\hline \multirow{2}{*}{$\begin{array}{l}\text { Growth of piglets } \\
\text { from } 15 \text { to } 21 \text { days of age }(\mathrm{kg})\end{array}$} & LSM & $1.87 \mathrm{ABa}$ & $1.31 \mathrm{ACb}$ & $2.05 \mathrm{~B}$ & $1.10 \mathrm{C}$ \\
\hline & $\mathrm{SE}$ & 0.22 & 0.10 & 0.16 & 0.15 \\
\hline \multirow{2}{*}{$\begin{array}{l}\text { Growth of piglets } \\
\text { from } 22 \text { to } 28 \text { days of age }(\mathrm{kg})\end{array}$} & LSM & 1.14 & 1.32 & 0.98 & 1.19 \\
\hline & $\mathrm{SE}$ & 0.19 & 0.14 & 0.07 & 0.18 \\
\hline \multirow{2}{*}{$\begin{array}{l}\text { Sow's milk yield per piglet from } \\
1 \text { to } 28 \text { days of lactation }(\mathrm{kg})\end{array}$} & LSM & $22.56 \mathrm{a}$ & 21.50 & $19.97 \mathrm{~b}$ & $19.43 \mathrm{~b}$ \\
\hline & $\mathrm{SE}$ & 1.21 & 0.88 & 0.49 & 1.15 \\
\hline \multirow{2}{*}{$\begin{array}{l}\text { Sow's milk yield from } 1 \text { to } 28 \\
\text { days of lactation }(\mathrm{kg})\end{array}$} & LSM & 214.32 & 193.52 & 191.43 & 204.06 \\
\hline & $\mathrm{SE}$ & 34.90 & 24.68 & 14.25 & 34.90 \\
\hline \multirow{2}{*}{$\begin{array}{l}\text { Deaths of piglets throughout } \\
\text { rearing from } 1 \text { to } 28 \text { days of age } \\
\text { (\%) }\end{array}$} & LSM & 3.43 & 7.96 & 10.23 & 2.33 \\
\hline & $\mathrm{SE}$ & 1.74 & 2.93 & 1.71 & 0.96 \\
\hline
\end{tabular}

Means with capital letters $(\mathrm{A}, \mathrm{B}, \mathrm{C})$ differ significantly at $\mathrm{P} \leq 0.01$.

Means with small letters (a,b) differ significantly at $\mathrm{P} \leq 0.05$. 
Within the CSN1S1 (Table 4), piglets from the sows of AA genotype achieved the highest weight and the best growth. Also, the milk yield from homozygous AA sows turned out to be the highest $(214.32 \mathrm{~kg})$. The results proved to be statistically significant at the level of $\mathrm{P} \leq 0.05$ and $\mathrm{P} \leq 0.01$.

Table 5. Effect of $\beta$-casein (CSN2) genotype on piglet rearing

\begin{tabular}{|c|c|c|c|c|}
\hline \multirow[b]{2}{*}{ Traits } & & \multicolumn{3}{|c|}{ CSN2 genotype } \\
\hline & & $\begin{array}{c}\text { AA } \\
n=291\end{array}$ & $\begin{array}{c}\mathrm{AB} \\
n=43\end{array}$ & $\begin{array}{c}\text { BB } \\
n=91\end{array}$ \\
\hline \multirow{2}{*}{$\begin{array}{l}\text { Weight of piglets } \\
\text { aged } 7 \text { days (kg) }\end{array}$} & LSM & $2.37 \mathrm{Aa}$ & $2.56 \mathrm{~b}$ & $2.58 \mathrm{~B}$ \\
\hline & $\mathrm{SE}$ & 0.03 & 0.09 & 0.06 \\
\hline \multirow{2}{*}{$\begin{array}{l}\text { Weight of piglets } \\
\text { aged } 14 \text { days }(\mathrm{kg})\end{array}$} & LSM & $4.28 \mathrm{Aa}$ & $4.60 \mathrm{~b}$ & $4.64 \mathrm{~B}$ \\
\hline & SE & 0.06 & 0.11 & 0.16 \\
\hline \multirow{2}{*}{$\begin{array}{l}\text { Weight of piglets } \\
\text { aged } 21 \text { days }(\mathrm{kg})\end{array}$} & LSM & $5.61 \mathrm{~A}$ & $5.86 \mathrm{~A}$ & $6.91 \mathrm{~B}$ \\
\hline & $\mathrm{SE}$ & 0.10 & 0.26 & 0.19 \\
\hline \multirow{2}{*}{$\begin{array}{l}\text { Weight of piglets } \\
\text { aged } 28 \text { days }(\mathrm{kg})\end{array}$} & LSM & $6.53 \mathrm{~A}$ & $6.92 \mathrm{~A}$ & $8.87 \mathrm{~B}$ \\
\hline & SE & 0.13 & 0.22 & 0.38 \\
\hline \multirow{2}{*}{$\begin{array}{l}\text { Growth of piglets } \\
\text { from } 1 \text { to } 7 \text { days of age }(\mathrm{kg})\end{array}$} & LSM & $0.91 \mathrm{~A}$ & 1.01 & $1.13 \mathrm{~B}$ \\
\hline & $\mathrm{SE}$ & 0.02 & 0.06 & 0.04 \\
\hline \multirow{2}{*}{$\begin{array}{l}\text { Growth of piglets } \\
\text { from } 8 \text { to } 14 \text { days of age }(\mathrm{kg})\end{array}$} & LSM & 1.90 & 2.08 & 2.03 \\
\hline & SE & 0.04 & 0.12 & 0.08 \\
\hline \multirow{2}{*}{$\begin{array}{l}\text { Growth of piglets } \\
\text { from } 15 \text { to } 21 \text { days of age }(\mathrm{kg})\end{array}$} & LSM & $1.50 \mathrm{~A}$ & $2.08 \mathrm{Ba}$ & $2.45 \mathrm{Bb}$ \\
\hline & SE & 0.06 & 0.15 & 0.11 \\
\hline \multirow{2}{*}{$\begin{array}{l}\text { Growth of piglets } \\
\text { from } 22 \text { to } 28 \text { days of age }(\mathrm{kg})\end{array}$} & LSM & $1.09 \mathrm{~A}$ & $1.18 \mathrm{~A}$ & $2.04 \mathrm{~B}$ \\
\hline & SE & 0.07 & 0.12 & 0.20 \\
\hline \multirow{2}{*}{$\begin{array}{l}\text { Sow's milk yield per piglet from } \\
1 \text { to } 28 \text { days of lactation }(\mathrm{kg})\end{array}$} & LSM & $19.49 \mathrm{~A}$ & $27.64 \mathrm{~B}$ & $20.93 \mathrm{~A}$ \\
\hline & $\mathrm{SE}$ & 0.42 & 1.26 & 0.74 \\
\hline \multirow{2}{*}{$\begin{array}{l}\text { Sow's milk yield from } 1 \text { to } 28 \\
\text { days of lactation }(\mathrm{kg})\end{array}$} & LSM & $183.73 \mathrm{a}$ & 207.82 & $230.28 \mathrm{~b}$ \\
\hline & $\mathrm{SE}$ & 11.77 & 31.15 & 22.03 \\
\hline \multirow{2}{*}{$\begin{array}{l}\text { Deaths of piglets throughout rear- } \\
\text { ing from } 1 \text { to } 28 \text { days of age (\%) }\end{array}$} & LSM & 8.25 & $16.30 \mathrm{a}$ & $5.50 \mathrm{~b}$ \\
\hline & SE & 1.62 & 4.23 & 2.91 \\
\hline
\end{tabular}

Means with capital letters (A, B) differ significantly at $\mathrm{P} \leq 0.01$.

Means with small letters $(a, b)$ differ significantly at $\mathrm{P} \leq 0.05$.

Table 5 shows the influence of $\beta$-casein (CSN2) on the characteristics under analysis. The CSN2-BB genotype proved to have the strongest relationship with the weight of the piglets during the rearing period. The weight of piglets aged 28 days was $2.34 \mathrm{~kg}$ higher than the weight of offspring from the sows of the CSN2-AA genotype. This was also reflected in their growth, but 8- to 14-day-old offspring from heterozygous CSN2-AB sows had the highest growth of $2.08 \mathrm{~kg}$. However, the difference proved to be statistically non-significant. Homozygous CSN2-BB sows were characterized by the best milk yield of $230.28 \mathrm{~kg}$, whereas CSN2-AB heterozygotes had the best milk yield per piglet $(27.64 \mathrm{~kg})$. The highest mortality was also recorded in this group. 
The analysis of $\kappa$-casein (CSN3) (Table 6) proved the AB genotype to be related with higher weight of piglets during the maternal nursing period. The advantage of piglets reared by $\mathrm{AB}$ heterozygotes over the offspring from homozygous $\mathrm{BB}$ sows with the lowest weight was $0.99 \mathrm{~kg}$ on day 28 . The offspring of CSN3-AB heterozygotes also had the highest growth and the productivity of their mothers proved to be statistically significant and amounted to $\alpha \leq 0.01$. The highest mortality (19.55\%) was recorded in the group of sows of the CSN3-AA genotype.

Table 6. Effect of $\kappa$-casein (CSN3) genotype on piglet rearing

\begin{tabular}{|c|c|c|c|c|}
\hline & \multicolumn{3}{|c|}{ CSN3 genotype } \\
\hline \multicolumn{2}{|l|}{ Traits } & \multirow{2}{*}{$\begin{array}{c}\text { AA } \\
\mathrm{n}=87\end{array}$} & \multirow{2}{*}{$\begin{array}{c}\mathrm{AB} \\
\mathrm{n}=207 \\
2.57 \mathrm{~B}\end{array}$} & \multirow{2}{*}{$\begin{array}{c}\text { BB } \\
\mathrm{n}=131 \\
2.38 \mathrm{C}\end{array}$} \\
\hline Weight of piglets & LSM & & & \\
\hline aged 7 days $(\mathrm{kg})$ & SE & 0.06 & 0.03 & 0.04 \\
\hline \multirow{2}{*}{$\begin{array}{l}\text { Weight of piglets } \\
\text { aged } 14 \text { days }(\mathrm{kg})\end{array}$} & LSM & $4.00 \mathrm{AC}$ & $4.64 \mathrm{~B}$ & $4.19 \mathrm{C}$ \\
\hline & SE & 0.11 & 0.07 & 0.08 \\
\hline \multirow{2}{*}{$\begin{array}{l}\text { Weight of piglets } \\
\text { aged } 21 \text { days }(\mathrm{kg})\end{array}$} & LSM & $5.20 \mathrm{~A} \mathrm{a}$ & $6.34 \mathrm{~B}$ & $5.71 \mathrm{~A} \mathrm{~b}$ \\
\hline & SE & 0.19 & 0.12 & 0.15 \\
\hline \multirow{2}{*}{$\begin{array}{l}\text { Weight of piglets } \\
\text { aged } 28 \text { days }(\mathrm{kg})\end{array}$} & LSM & $6.58 \mathrm{~b}$ & $7.23 \mathrm{~A} \mathrm{a}$ & $6.24 \mathrm{~B}$ \\
\hline & SE & 0.28 & 0.15 & 0.19 \\
\hline \multirow{2}{*}{$\begin{array}{l}\text { Growth of piglets } \\
\text { from } 1 \text { to } 7 \text { days of age }(\mathrm{kg})\end{array}$} & LSM & $0.74 \mathrm{~A}$ & $1.08 \mathrm{~B}$ & $0.92 \mathrm{C}$ \\
\hline & SE & 0.05 & 0.02 & 0.03 \\
\hline \multirow{2}{*}{$\begin{array}{l}\text { Growth of piglets } \\
\text { from } 8 \text { to } 14 \text { days of age }(\mathrm{kg})\end{array}$} & LSM & $1.83 \mathrm{~b}$ & $2.06 \mathrm{~A} \mathrm{a}$ & $1.80 \mathrm{~B}$ \\
\hline & SE & 0.08 & 0.05 & 0.06 \\
\hline \multirow{2}{*}{$\begin{array}{l}\text { Growth of piglets } \\
\text { from } 15 \text { to } 21 \text { days of age }(\mathrm{kg})\end{array}$} & LSM & $1.31 \mathrm{~A}$ & $2.00 \mathrm{~B} \mathrm{a}$ & $1.71 \mathrm{~B} \mathrm{~b}$ \\
\hline & $\mathrm{SE}$ & 0.12 & 0.07 & 0.09 \\
\hline \multirow{2}{*}{$\begin{array}{l}\text { Growth of piglets } \\
\text { from } 22 \text { to } 28 \text { days of age }(\mathrm{kg})\end{array}$} & LSM & $1.29 \mathrm{~A}$ & $1.21 \mathrm{~A}$ & $0.91 \mathrm{~B}$ \\
\hline & SE & 0.14 & 0.08 & 0.10 \\
\hline \multirow{2}{*}{$\begin{array}{l}\text { Sow's milk yield per piglet from } 1 \text { to } \\
28 \text { days of lactation }(\mathrm{kg})\end{array}$} & LSM & 19.88 & $21.94 \mathrm{~A}$ & $18.40 \mathrm{~B}$ \\
\hline & $\mathrm{SE}$ & 0.94 & 0.51 & 0.64 \\
\hline \multirow{2}{*}{$\begin{array}{l}\text { Sow's milk yield from } 1 \text { to } 28 \text { days of } \\
\text { lactation }(\mathrm{kg})\end{array}$} & LSM & $144.12 \mathrm{~A}$ & $217.25 \mathrm{~B}$ & 193.17 \\
\hline & SE & 19.07 & 12.06 & 15.60 \\
\hline \multirow{2}{*}{$\begin{array}{l}\text { Deaths of piglets throughout rearing } \\
\text { from } 1 \text { to } 28 \text { days of age }(\%)\end{array}$} & LSM & $19.55 \mathrm{~A}$ & $6.77 \mathrm{~B}$ & $3.82 \mathrm{~B}$ \\
\hline & SE & 2.93 & 1.98 & 2.38 \\
\hline
\end{tabular}

Means with capital letters $(\mathrm{A}, \mathrm{B}, \mathrm{C})$ differ significantly at $\mathrm{P} \leq 0.01$.

Means with small letters $(\mathrm{a}, \mathrm{b})$ differ significantly at $\mathrm{P} \leq 0.05$.

Table 7 shows the influence of $\beta$-lactoglobulin (LGB) genotypes on piglet rearing. Statistically significant relationships between LGB genotypes were observed at the level of $\mathrm{P} \leq 0.05$ and $\mathrm{P} \leq 0.01$. Offspring from LGB-AA homozygotes had the best results. At the age of 28 days, piglets' average weight was higher by $0.76 \mathrm{~kg}$. Also, other productivity characteristics proved to be better in the sows of that genotype. 
Table 7. Effect of $\beta$-lactoglobulin (LGB) genotype on piglet rearing

\begin{tabular}{|c|c|c|c|}
\hline \multirow{2}{*}{ Traits } & & \multicolumn{2}{|c|}{ LGB genotype } \\
\hline & & $\begin{array}{c}\mathrm{AA} \\
\mathrm{n}=73\end{array}$ & $\begin{array}{c}\mathrm{BB} \\
\mathrm{n}=352\end{array}$ \\
\hline \multirow{2}{*}{$\begin{array}{l}\text { Weight of piglets } \\
\text { aged } 7 \text { days }(\mathrm{kg})\end{array}$} & LSM & $2.63 \mathrm{~A}$ & $2.39 \mathrm{~B}$ \\
\hline & SE & 0.06 & 0.03 \\
\hline \multirow{2}{*}{$\begin{array}{l}\text { Weight of piglets } \\
\text { aged } 14 \text { days }(\mathrm{kg})\end{array}$} & LSM & $4.93 \mathrm{~A}$ & $4.26 \mathrm{~B}$ \\
\hline & $\mathrm{SE}$ & 0.11 & 0.05 \\
\hline \multirow{2}{*}{$\begin{array}{l}\text { Weight of piglets } \\
\text { aged } 21 \text { days }(\mathrm{kg})\end{array}$} & LSM & 6.07 & 5.88 \\
\hline & $\mathrm{SE}$ & 0.23 & 0.10 \\
\hline \multirow{2}{*}{$\begin{array}{l}\text { Weight of piglets } \\
\text { aged } 28 \text { days }(\mathrm{kg})\end{array}$} & LSM & $7.41 \mathrm{~A}$ & $6.65 \mathrm{~B}$ \\
\hline & $\mathrm{SE}$ & 0.25 & 0.13 \\
\hline \multirow{2}{*}{$\begin{array}{l}\text { Growth of piglets } \\
\text { from } 1 \text { to } 7 \text { days of age }(\mathrm{kg})\end{array}$} & LSM & $1.08 \mathrm{~A}$ & $0.94 \mathrm{~B}$ \\
\hline & $\mathrm{SE}$ & 0.05 & 0.02 \\
\hline \multirow{2}{*}{$\begin{array}{l}\text { Growth of piglets } \\
\text { from } 8 \text { to } 14 \text { days of age }(\mathrm{kg})\end{array}$} & LSM & $2.31 \mathrm{~A}$ & $1.85 \mathrm{~B}$ \\
\hline & $\mathrm{SE}$ & 0.08 & 0.04 \\
\hline \multirow{2}{*}{$\begin{array}{l}\text { Growth of piglets } \\
\text { from } 15 \text { to } 21 \text { days of age }(\mathrm{kg})\end{array}$} & LSM & 1.54 & 1.81 \\
\hline & SE & 0.14 & 0.06 \\
\hline \multirow{2}{*}{$\begin{array}{l}\text { Growth of piglets } \\
\text { from } 22 \text { to } 28 \text { days of age }(\mathrm{kg})\end{array}$} & LSM & 1.14 & 1.09 \\
\hline & $\mathrm{SE}$ & 0.13 & 0.07 \\
\hline \multirow{2}{*}{$\begin{array}{l}\text { Sow's milk yield per piglet from } 1 \text { to } 28 \text { days } \\
\text { of lactation }(\mathrm{kg})\end{array}$} & LSM & $22.35 \mathrm{a}$ & $19.99 \mathrm{~b}$ \\
\hline & $\mathrm{SE}$ & 0.85 & 0.42 \\
\hline \multirow{2}{*}{$\begin{array}{l}\text { Sow's milk yield from } 1 \text { to } 28 \text { days of lactation } \\
(\mathrm{kg})\end{array}$} & LSM & 212.33 & 191.16 \\
\hline & $\mathrm{SE}$ & 23.16 & 11.58 \\
\hline \multirow{2}{*}{$\begin{array}{l}\text { Deaths of piglets throughout rearing from } 1 \text { to } \\
28 \text { days of age (\%) }\end{array}$} & LSM & 2.75 & 9.67 \\
\hline & SE & 1.48 & 3.25 \\
\hline
\end{tabular}

Means with capital letters (A, B) differ significantly at $\mathrm{P} \leq 0.01$.

Means with small letters $(a, b)$ differ significantly at $\mathrm{P} \leq 0.05$.

\section{Discussion}

The issue of milk protein polymorphism in dairy cows, which is associated with the use of milk as food, has been thoroughly investigated and described. Aschaffenburg and Drewry (1957) are considered to be the precursors who initiated investigations of milk protein genetic polymorphism in the 1950s.

In the population of sows under investigation, the highest frequency in the CSN1S1 fraction was determined for the BB genotype (60\%). Many authors found prevalence of this genotype also in cow's milk (Walawski et al., 1994; Miciński et al., 2008).

In 1966, Glasnak reported polymorphism of $\beta$-casein in sow's milk and 3 allele variants: $\mathrm{A}, \mathrm{B}$ and $\mathrm{C}$. In the study under analysis, we obtained 3 genotype variants, where the sows with CSN2-AA genotype were in the majority (70\%). Ziemiński et al. (2005) and Sitkowska et al. (2008) as well as many other researchers emphasized the fact that AA homozygotes were predominant in all breed groups. 
The results of the present experiment demonstrated that frequencies of $\kappa$-casein (CSN3) genotypes were arranged divergently in comparison with investigations conducted by Sitkowska et al. (2009) on ruminant milk. The above-mentioned authors proved that homozygous AA animals were a prevalent group. Identical conclusions were drawn by Ziemiński et al. (2000). However, in a $\kappa$-casein genotype system analysed by Litwińczuk et al. (2006), heterozygotic animals prevailed, just as in the present investigations.

As far as $\beta$-lactoglobulin is concerned, there were only two homozygous genotypes (LGB-AA and BB) in the data under analysis. Numerous authors also presented diversified data. Mele et al. (2007) as well as Kawęcka and Radko (2011) observed a considerable share of heterozygotes in experiments carried out on sheep.

The impact of genotypes of protein fractions on traits associated with rearing has not been investigated to date. In recent years, investigations have been carried out to determine the influence of protein genetic variants in beef and beef-dairy cattle on calf rearing effectiveness (Litwińczuk et al., 2006).

The results obtained in the course of the present study showed that for the as 1casein (CSN1S1) and $\beta$-casein (CSN2) fractions, the highest weight, the best body weight gains and the smallest number of deaths were recorded for progeny derived from CSN1S1 AA and CSN2 BB homozygous sows.

Schmidely et al. (2002) and Barłowska et al. (2007) proved that goats of the CSN1S1-AA homozygous genotype produced milk with a higher concentration of its components, i.e. fat and protein, thus achieving better yields.

Most researchers usually focus their interest on $\kappa$-casein and $\beta$-lactoglobulin. The $\kappa$-casein fraction (CSN3) plays a substantial role in offspring rearing because it has a high nutritional value (Litwińczuk et al., 2006). In the present study, the best results were recorded in the case of progeny of CSN3-AB heterozygotic sows. The situation in body weight gains changed in favour of progeny derived from CSN3-AA homozygous sows in the period from days 22 to 28 of rearing. This can be attributed to the fact that the proportion of deaths in this group turned out to be the highest $(19.55 \%)$, significantly reducing the number of piglets; consequently, those that remained could ingest greater quantities of feed (milk).

Henderson and Marshall (1996) found a relationship between $\kappa$-casein genetic variants and calf rearing. It is clear from their experiments that offspring from cows of the CSN3-AB genotype achieved the highest daily growth and the highest body weight at weaning. Król (2003) observed a similar dependence in Limousin and Hereford cows.

$\beta$-lactoglobulin (LGB) as a protein fraction exhibits a supportive effect in viral infections and was reported to counteract bacterial infections. Different authors present opposing results of the research on the influence of $\beta$-lactoglobulin genetic variants (LGB). The results of our experiment proved that progeny of LGB-AA genotype sows was characterized by the best results from the economic point of view.

Gurcan (2011) obtained similar results, where cattle of the LGB-AA genotype achieved the best coefficients.

Litwińczuk et al. (2006) proved that calves from mothers of the LGB-AB genotype were characterized by the highest growth. A study conducted by Curi et al. 
(2005) showed that no LGB genotype had a significant influence on productive characteristics of young beef cattle.

Summing up the results of our research, it can be concluded that milk from sows of the AA CSN1S1 and AA LGB genotype appeared to be the most valuable and nourishing as confirmed by the fact that these sows reared piglets that were characterized by the best production results, i.e. body weight, weight gains and the lowest number of deaths. On the other hand, piglets derived from litters of sows of the AA CSN3 genotype developed least dynamically.

Investigations on the utilization of milk protein polymorphism as well as the recognition of its genetic sequence as a parameter in swine selection and piglet rearing are fully justified. These issues arouse increasing interest and experiments will be continued on larger populations of sows of both native and commercial breeds.

\section{References}

Aschaffenburg R., Drewry J. (1957). Improved method for the preparation of crystalline $\beta$-lactoglobulin and $\alpha$-lactalbumin from cow's milk. Biochem. J., 65 (2): 273-277.

Barłowska J., Litwińczuk Z., Florek M., Kędzierska-Matysek M. (2007). Yield and composition of goat milk from 4 Polish breeds differing in as1-casein genotype (in Polish). Med. Weter., 63 (12): 1600-1603.

B or u t a O., J a s e k S., G or a jew sk a E. (2009). Variability of chemical composition of sow milk depending on the breed, breast, and the mammary gland and the parameters of piglet rearing (in Polish). Zesz. Nauk. UP Wrocław LVIII, 572: 9-19.

B u c z yń sk i J.T., S k r z y p c za k E., P a nek A., S z u l c K. (2006). Chemical composition of milk of Złotnicka White sows during lactation. Ann. Anim. Sci., Suppl., 2/2: 315-319.

Chaneton L., Pérez Sá ez J.M., B us smann L.E. (2011). Antimicrobial activity of bovine $\beta$-lactoglobulin against mastitis-causing bacteria. J. Dairy Sci., 94 (1): 138-45.

C u r i R.A.,O 1 i v e i r a H.N., G i m e n e s M.A.,S i 1 v e ir a A.C.,L o p e s C.R.(2005).EffectsofCSN3 and LGB gene polymorphisms on production traits in beef cattle. Genet. Mol. Biol., 28 (2): 262-266.

F lower D.R., North A.C., S a n s om C.E. (2000). The lipocalin protein family: Structural and sequence overview. Biochim. Biophys. Acta., 148 (2): 9-24.

Gigli I., Riggio V., Montele on e G., Cacioppo D., Ros a A.J.M., Maizon D. (2007). Relationship between beta lactoglobulin and subclinical mastitis in Valle del Belice sheep breed. J. Anim. Sci., 6 (1): 140-142.

G 1 a s n a k V. (1966). Protein polymorphism in sow's milk. Proc. Xth Eur. Conf. Anim. Blood Grps and Biochem. Polym. (Paris), pp. 433-435.

Gu r c a n E.K. (2011). Association between milk protein polymorphism and milk production traits in Black and White dairy cattle in Turkey. Afr. J. Biotechnol., 10 (6): 1044-1048.

H a E., Z e mel M.B. (2003). Functional properties of whey, whey components, and essential amino acids: mechanisms underlying health benefits for active people. J. Nutr. Biochem., 14: 251-258.

H e n d e r s o n D.A., M a r s h a 11 D.M. (1996). Kappa-casein genotype effects in a multiple breed beef cattle population. J. Anim. Sci., Suppl., 1: 74-121.

K a w ę c k a A., R a d k o A. (2011). Genetic polymorphism of $\beta$-lactoglobulin in sheep raised for milk production. J. Appl. Anim. Res., 39 (1): 68-71.

K ró 1 J. (2003). Association of genetic variants of milk proteins with a yield of dairy cows, meat, and the results of rearing their offspring. Ann. UMCS, 21 (1): 81-99.

Król J., Litwińczuk A., Zarajczyk A., Litwińczuk Z. (2008). Alpha-lactalbumin and beta-lactoglobulin as a biologically active protein fraction of milk. Med. Weter., 64 (12): 1375-1378.

K ró 1 J., Litwín c zuk Z., B rodzi a k A., S a w i c k a-Z u gaj W. (2010). Bioactive protein content in milk from local breeds of cows included in the genetic resources conservation programme. Ann. Anim. Sci., 10 (3): 213-221. 
Litwińczuk A., Barłowska J., Król J., Litwińczuk Z. (2006). Milk protein polymorphisms as genetic markers of useful traits of dairy and beef cattle (in Polish). Med. Weter., 62 (1): 6-10.

L y $\mathrm{nch}$ M., W elsh B. (1998). Genetics and analysis of quantitative traits. Sinauer Associates Inc., Sunderland Massachusetts (USA).

Mele M., Conte G., Serra A., Buccioni A., Secchiari P. (2007). Relationship between beta-lactoglobulin polymorphism and milk fatty acid composition in milk of Massese dairy ewes. Small Ruminant Res., 73: 37-44.

Meza-Nieto M.A., González-Córdova A.F., Becerril-Pérez C.M., Ruíz-Lópe z F.J., Día z - R i ve r a P., V a ll e jo - C ord ob a B. (2010). Genetic polymorphism of $\beta$-lactoglobulin in cow's milk of Holstein and tropical milking Criollo. Agrociencia, 44 (5): 531-539.

M i c ha l c ova A., K r u p ov a Z. (2007). Influence of composite $\kappa$-casein and $\beta$-lactoglobulin genotypes on composition, rennetability and heat stability of milk of cows of Slovak Pied breed. Czech J. Anim. Sci., 52 (9): 292-298.

M i c ińs ki J., P o g or ze lsk a J., B a rańs k i W. (2008). Operational parameters of HF breed element, depending on the genetic variants of milk proteins selected (in Polish). Med. Weter., 64 (9): $1136-1140$.

Nutrient Requirements of Pigs (1993). The Kielanowski Institute of Animal Physiology and Nutrition, Jabłonna (Poland). Omnitech Press. Warsaw.

P ér e z, M.D., C a lv o M. (1995). Interaction of beta-lactoglobulin with retinol and fatty acids and its role as a possible biological function for this protein: a review. J. Dairy Sci., 78 (5): 978-988.

Rekiel A., Więcek J., B eyg a K. (2011). Analysis of the relationship between fatness of late pregnant and lactating sows and selected lipid parameters of blood, colostrum and milk. Ann. Anim. Sci., 11 (4): 487-495.

Schmidely Ph., Meschy F., Tessier J., S a uvant D. (2002). Lactation response and nitrogen, calcium, and phosphorus utilization of dairy goats differing by the genotype for as 1-caseine in milk, and fed diets varying in crude protein concentration. J. Dairy Sci., 85: 2299-2307.

Sitkowska B., Neja W., Wiśniewska E. (2008). Relations between kappa-casein polymorphism (CSN3) and milk performance traits in heifer cows. J. Cent. Eur. Agric., 4: 641-644.

Sitkowska B., Neja W., Wiśniewska E., Mroczkowski S., S awa E. (2009). Effect of the polymorphic composite forms of beta-lactoglobulin on the milk yield and chemical composition in maximum lactation. J. Cent. Eur. Agric., 3: 251-254.

Skrzy p c zak E., B a b i c z M., S z u l c K., M arc is z M., B u c zyńs ki J.T. (2012). The analysis of variability of $\mathrm{pH}$ level and somatic cell count (SCC) in the colostrum and milk of Złotnicka White sows. Afr. J. Biotechnol., 11 (20): 4687-4692.

S zu l c K.,S krzy p czak G.,B u c zyń sk i J.T.,S t a n isła w sk i D.,J a n k ow sk a A.,K ne ch t D. (2012). Evaluation of fattening and slaughter performance and determination of meat quality in Zlotnicka Spotted pigs and this crosses with the Duroc breed. Czech J. Anim., 57: 95-107.

Wa lawski K., S ow iński G., C zarnik U., Z abolewicz T. (1994). Beta-lactoglobulin and kappa-casein polymorphism in relation to production traits and technological properties of milk in the herd of Polish Black-and-White cows. Genet. Pol., 35: 93-108.

W illi a m s I.H. (1995). Sows' milk as a major nutrient source before weaning. In: Cranwell P.D., Hennessy D.P. (eds), Manipulating Pig Production V. Australasian Pig Science Association, Werribee, VIC, Australia, pp. 107-113.

Ziemiński R., Juszczak J., Czarniak U., Ćwikła A., Zabolewicz T., Walawski K. (2005). Relationship between milk protein polymorphism and variations in yields and composition of milk of Black and White cows from Kiekrz Agricultural Estate (in Polish). Acta Sci. Pol. Zoot., 4: $163-170$.

Zi e m iński R., Jus zc zak J., W a law ski K. (2000). Polymorphism of milk proteins in Black-and-White and Red-and-White cows in relation to their usefulness (in Polish). Rocz. Nauk. Zoot., Supl., 5: 59-63.

Zw i e r z ch ow sk i L. (2009). Reading from the genomes (in Polish). Panorama Genomika Zwierząt, Academia, 4 (20): 24-27. 


\section{EWA SKRZYPCZAK, MAREK BABICZ, KAROLINA SZULC, ANNA WALENDOWSKA, ANNA PANEK}

\section{Wplyw polimorfizmu bialek mleka loch na odchów prosiąt}

\section{STRESZCZENIE}

Celem podjętych badań było dostarczenie informacji na temat związku między polimorficznymi frakcjami białek mleka a rezultatami w odchowie prosiąt loch rasy złotnickiej białej. Materiał zwierzęcy stanowiło 20 loch rodzimej rasy złotnickiej białej. Świnie ras złotnickich objęte są Krajowym Programem Ochrony Zasobów Genetycznych.

Badanie obejmowało dwie kolejne laktacje loch (2. i 3.). W czasie trwania doświadczenia określono następujące parametry: liczbę i masę prosiąt w 1., 7., 14., 21. i 28. dniu życia, przyrosty poszczególnych prosiąt w okresie od 1. do 7. dnia, od 8. do 14 . dnia, od 15. do 21 . dnia i od 22. do 28 . dnia oraz straty za cały okres odchowu, tj. od 1 . do 28 . dnia życia.

Łącznie poddano doświadczeniu 425 prosiąt, pochodzących z 40 miotów (20 loch $\times 2$ laktacje). W wyniku rozdziału elektroforetycznego w mleku loch wyizolowano 4 następujące frakcje białkowe: as1-kazeinę (CSN1S1) genotypy: AA, AB, BB, BC; $\beta$-kazeinę (CSN2) genotypy: AA, AB, BB; $\kappa$-kazeinę (CSN3) genotypy: AA, AB, BB oraz $\beta$-laktoglobulinę (LGB) genotypy: AA, BB. Prace badawcze dowiodły, że mleko loch o genotypie AA CSN1S1 i AA LGB wydaje się być najbardziej wartościowe i odżywcze. Efektem tego był fakt, że lochy te odchowały prosięta, które charakteryzowały się najlepszymi wynikami produkcyjnymi, tzn. masą, przyrostami i najmniejszym procentem upadków.

Najmniej dynamiczne wyniki osiągnęły prosięta pochodzące $\mathrm{z}$ miotów loch o genotypie AA-CSN3. 